\title{
Low occurrence of equine herpesvirus 1 (EHV-1) as cause of abortion and perinatal mortality in Brazil*
}

\author{
Baixa ocorrência de herpes-vírus equino 1 (HVE-1) como \\ causa de abortamento e mortalidade perinatal no Brasil
}

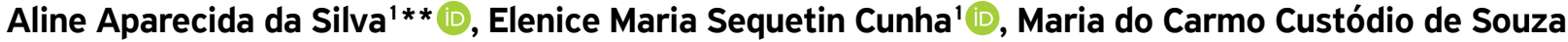 \\ Hunold Lara', Eliana Monteforte Cassaro Villalobos ${ }^{1} \mathbb{D}$, Alessandra Figueiredo de Castro Nassar ${ }^{1}$ (D), \\ Enio Mori² (D), Carolina Natalia Zanuzzi³ ${ }^{3}$ Cecília Mônica Galosi ${ }^{1}$ (D), Claudia Del Fava' (iD)
}

\begin{abstract}
Equine herpesvirus type 1 (EHV-1) is an important pathogen that causes abortion, neonatal disease, respiratory disorders, and neurological syndrome in equine populations worldwide. To evaluate EHV-1 as a cause of abortion and perinatal mortality in Brazil, tissue samples from 105 aborted equine fetuses, stillbirths, and foals up to one month of age were examined using virus isolation, immunohistochemistry (IHC), histopathology, and nested polymerase chain reaction (PCR). Two fetuses were positive for EHV-1 by PCR, one of which showed syncytia and eosinophilic intranuclear inclusion bodies in bronchial epithelia, but it was negative by virus isolation. The other showed no characteristic histological lesions, but it was positive by viral isolation. No sample was positive by IHC. The results presented low occurrence of EHV-1 in the studied population and suggested that the use of a combination of techniques increases the likelihood of an accurate diagnosis of EHV-1.
\end{abstract}

KEYWORDS: equine herpesvirus type 1; histopathology; immunohistochemistry; polymerase chain reaction; virus isolation.
RESUMO: O herpes-vírus equino tipo 1 (HVE-1) é um importante agente patogênico causador de aborto, doença neonatal, distúrbios respiratórios e síndrome neurológica em populaçōes de equinos em todo o mundo. Para avaliar a ocorrência do HVE-1 como agente causal de abortamento e mortalidade perinatal no Brasil, foram examinadas amostras de 105 fetos equinos abortados, natimortos e potros de até 1 mês de idade, utilizando as técnicas de isolamento viral, imuno-histoquímica (IHQ), histopatologia e reação em cadeia da polimerase aninhada (nested-PCR). Dois fetos foram positivos na análise de PCR, e um deles apresentou corpúsculos de inclusão viral eosinofílicos e sincícios no epitélio brônquico, porém foi negativo na análise de isolamento viral. $\mathrm{O}$ outro feto não apresentou lesōes histológicas características de infecção herpética, mas foi positivo na análise de isolamento viral. Nenhuma amostra apresentou resultado positivo pela análise de IHQ. Os resultados demonstraram baixa ocorrência de HVE-1 na população estudada e que o uso de diferentes técnicas diagnósticas aumenta a probabilidade de um diagnóstico preciso para o HVE-1.

PALAVRAS-CHAVE: herpes-vírus equino tipo 1; histopatologia; imuno-histoquímica; reação em cadeia da polimerase; isolamento viral. 


\section{INTRODUCTION}

Equine herpesvirus type 1 (EHV-1), an enveloped virus that causes respiratory and neurological clinical signs, abortion, and neonatal death, has been isolated from aborted equine fetuses in Brazil and other areas throughout the world (HONG et al., 1993; MOREIRA et al., 1998; LAUGIER et al., 2011). The principal sources of natural infection of EHV-1 are respiratory secretions from the nasopharynx, aborted fetuses, fetal membranes, secretions from the reproductive tract of mares immediately post-abortion (ALLEN, 2002). Mechanical transmission by contaminated fomites is also a usual source of infection (ALLEN, 2002).

The primary EHV-1 input port is the epithelium of the upper respiratory tract mucosa with local virus multiplication. The virus is transported by $\mathrm{B}$ and $\mathrm{T}$ lymphocytes to the uterus and other organs via circulatory system (RUIZSÁENZ et al., 2008), potentially leading to severe vasculitis and multifocal endometrial thrombosis that may cause abortion in the final trimester of pregnancy, perinatal death, and/ or myeloencephalopathy and neurological syndrome in the foal (CRABB; STUDDERT, 1995; ALLEN, 2002; RUIZSÁENZ et al., 2008).

Several factors complicate accurate diagnosis of EHV-1, including the overlap of respiratory and neurological clinical signs with diseases induced by other pathogens, for example, equine influenza virus subtypes 1 and 2 and equine adenovirus type 1 , which cause respiratory infection; equine viral arteritis associated with respiratory disease and abortion; the protozoan Sarcocystis neurona; and the rabies virus causing neurological disorders (MCCHESNEY et al., 1970; SMITH, 1993; FERNANDES, 1999).

EHV-1 exhibits the potential to remain latent in the trigeminal nerve ganglia and lymphoid tissue and may undergo endogenous reactivation from a state of immunosuppression at any time in the life of its host. It presents a challenge to both clinical and laboratory diagnosis, requiring highly sensitive polymerase chain reaction (PCR) methods capable of identifying latent viruses (WELCH et al., 1992; ALLEN et al., 2008; BALASURIYA et al., 2015).

Pathological lesions of liver, kidney, heart, lung, spleen, and brain of fetuses aborted due to EHV-1 infection are characterized by mononuclear inflammatory infiltrate and focal necrosis (DEL PIERO, 1999; OIE, 2015). Syncytia in lungs and liver parenchyma and eosinophilic intranuclear inclusion bodies in bronchiolar epithelia or in cells at the periphery of necrotic hepatic areas are considered pathognomonic lesions for EHV-1 (SZEREDI et al., 2003a; HORNYÁK et al., 2006; OIE, 2015).

Among methods recommended by the World Organization for Animal Health (OIE) for EHV-1 detection, PCR is considered a rapid and sensitive technique. Virus isolation is cited as useful, particularly for the detection of viremia, since
EHV-1-associated abortions and foal neonatal deaths usually produce a cytopathic effect in 1-3 days, when there is a high level of virus in the tissue. Immunohistochemistry and immunofluorescence are suggested to be useful and relatively straightforward approaches for rapid diagnosis of EHV-1induced abortion in fresh or embedded tissue (OIE, 2015).

Given the importance of this agent as a cause of reproductive problems in horses and the need to perform differential diagnosis of infectious diseases that cause equine abortion and perinatal mortality, the present study aimed to evaluate the occurrence of EHV-1 in samples of aborted equine fetuses, stillbirths, and foals up to one month of age from several Brazilian regions.

\section{MATERIALS AND METHODS}

\section{Sampled animals}

Tissue samples from 105 animals referred for diagnosis of EHV-1 to laboratories of the Research and Development Center for Animal Health of the Instituto Biológico from January 2010 to July 2013 were examined. The samples were obtained from 37 fetuses, three stillbirths, 21 foals under 1 month of age, and 44 samples of unknown age. The sampled animals were submitted by private veterinarians from eleven Brazilian states. The majority came from Southeastern regions, including São Paulo $(n=51)$, Rio de Janeiro $(n=9)$, and Minas Gerais $(\mathrm{n}=8)$; followed by the Southern states Paraná $(\mathrm{n}=17)$, Rio Grande do Sul $(\mathrm{n}=3)$, Mato Grosso do Sul $(\mathrm{n}=2)$; and Santa Catarina $(\mathrm{n}=1)$; the Midwestern region Distrito Federal $(\mathrm{n}=1)$ and the Northeastern states Pará $(\mathrm{n}=1)$, Sergipe $(\mathrm{n}=1)$, and Tocantins $(\mathrm{n}=1)$. The geographic origin of ten samples was not reported. This project was approved by the Ethics Committee on Animal Experiments of the Instituto Biológico (CETEA-IB) on 26 October 2010, registration number CETEA 106/10.

\section{Tissue samples}

Tissue samples included central nervous system (CNS) ( $\mathrm{n}=44)$, lungs (83), heart (67), liver (82), kidney (86), spleen (74), and thymus (26). Refrigerated tissues were subjected to virus isolation and PCR performed by the Rabies and Viral Encephalitis Laboratory, and fragments fixed in $10 \%$ buffered formalin for histology and immunohistochemistry (IHC) were processed at the Pathology Laboratory.

\section{Histology}

Tissues were fixed in 10\% buffered formalin for $48 \mathrm{~h}$, transferred to $70 \%$ ethanol, dehydrated in an ethanol series, cleared in xylene, and embedded in paraffin. Sections were cut at $3 \mu \mathrm{m}$, 
deparaffinized, rehydrated, and stained with haematoxylin and eosin (H\&E) (PROPHET et al., 1995).

\section{Immunohistochemistry}

Immunohistochemistry (IHC) was conducted using primary polyclonal anti-EHV-1 antibody (VMRD, catalog 210-70ERV, Pullman, Washington, United States), a labeled streptavidin biotin kit (LSAB + System - HRP, Dako ${ }^{\circledR}$ ref. K0690, Cytomation, Carpinteria, California, United States), with 3,3'diaminobenzidine chromogen solution (DAB - Dako ${ }^{\oplus}$ code ref. K3468) used as substrate.

Blocks for IHC were sectioned at $3 \mu \mathrm{m}$ and placed on silanized glass microscope slides. Slides were deparaffinized in xylene at $37^{\circ} \mathrm{C}$ for $1 \mathrm{~h}$, diaphanized in two xylene baths for $15 \mathrm{~min}$ each, and placed in xylene and absolute ethanol (1:1) for $15 \mathrm{~min}$. Slides were bathed in a descending ethanol series, and rinsed for $5 \mathrm{~min}$ in phosphate buffered saline (PBS) ( $\mathrm{pH} 7.4)$.

Endogenous peroxidase was blocked by $6 \%$ hydrogen peroxide $\left(\mathrm{H}_{2} \mathrm{O}_{2}\right)\left(20 \mathrm{~mL}\right.$ of $30 \% \mathrm{H}_{2} \mathrm{O}_{2}$ in $80 \mathrm{~mL}$ of methanol) for $30 \mathrm{~min}$. Slides were subsequently immersed in citrate buffer ( $\mathrm{pH}$ 6.0) and placed in a microwave oven for $15 \mathrm{~min}$ at high power (1,000 watts) for antigen retrieval, and then washed three times in PBS for 5 min. Nonspecific reactions were blocked by immersion in 5\% skimmed milk in PBS for $1 \mathrm{~h}$ at room temperature under gentle agitation using a magnetic stirrer and washed as described previously.

The slides were incubated with goat polyclonal anti-EHV-1 antibody diluted 1:1,000 in 5\% skimmed milk in a humid chamber at $37^{\circ} \mathrm{C}$ for $30 \mathrm{~min}$, followed by incubation with a labeled streptavidin-biotin kit (combination anti-mouse, -rabbit, and-goat immunoglobulin; Dako ${ }^{\circledR}$ ). Slides were incubated with streptavidin-HRP conjugate for $45 \mathrm{~min}$ in a humid chamber at room temperature and then washed with PBS for 5 min.

The reaction was revealed with $\mathrm{DAB}$ chromogen diluted in substrate buffer and processed according to the manufacturer's instructions (DAB - Dako ${ }^{\circledR}$ code ref K3468). IHC slides were counterstained with Harris hematoxylin for $8 \mathrm{sec}$, rinsed in a gentle flow of running water for 6-8 min, dehydrated in an ascending ethanol series, cleared in xylene, mounted with Entellan $\left(\right.$ Merck $\left.^{\circledR}\right)$, and examined by optical microscopy.

Lungs and brain of uninfected female Syrian hamsters, Mesocricetus auratus, 40-50 g, were used as negative controls.

\section{Virus isolation}

One $\mathrm{mL}$ of $20 \%$ fetal organ suspension $-2 \mathrm{~g}$ of each organ tissue macerated with $8 \mathrm{~mL}$ Eagle's minimum essential medium (EMEM) solution - was inoculated into a monolayer culture of Vero cells at $37^{\circ} \mathrm{C}$ for $1 \mathrm{~h}$ (LARA et al., 2008). At the end of the attachment period, cell monolayers were rinsed with $6 \mathrm{~mL}$ maintenance medium (EMEM containing 2\% fetal calf serum supplemented with $200 \mathrm{U} / \mathrm{mL}$ penicillin, $200 \mathrm{mg} / \mathrm{mL}$ streptomycin, and $50 \mathrm{U} / \mathrm{mL}$ nystatin) and incubated at $37^{\circ} \mathrm{C}$. Three blind passages were conducted at 7-day intervals, and cells were assessed for herpesvirus cytopathic effect characterized by the presence of rounded, retractile cells, lysis, or syncytia formation.

\section{Polymerase chain reaction}

Deoxyribonucleic acid (DNA) was extracted from 20\% fetal organ suspensions (CHOMCZYNSKI, 1993). PCR were performed using primers that hybridize to highly conserved $\mathrm{gB}$ gene regions using the inner primers (Invitrogen ${ }^{\circledast}$ Brazil, São Paulo, São Paulo, Brazil) (P1 forward 5'-CTTGTGAGATCTAACCGCAC-3'/P2 outer reverse 5'-GGGTATAGAGCTTTCATGGG-3' and P1/P3 inner reverse 5'-GCGTTATAGCTATCACGTCC-3') (MORI et al., 2009). Amplification was performed in a sterile $0.5 \mathrm{~mL}$ microcentrifuge tube on a total volume of $50 \mu \mathrm{L}$ reaction mixture containing $100 \mathrm{ng}$ of DNA sample, $0.5 \mu \mathrm{M}$ of each primer, $0.2 \mathrm{mM}$ of each deoxynucleotide (dNTP) mixture (Invitrogen, Carlsbad, California, United States), 2.5 units of Taq DNA polymerase Platinum ${ }^{\circledR}$ (Invitrogen ${ }^{\circledR}$ Brazil, São Paulo, São Paulo, Brazil), 1× of PCR buffer Minus Mg (20 mM of Tris- $\mathrm{HCl}$, pH 8.4, $50 \mathrm{mM}$ of $\mathrm{KCl}$ ), $1.5 \mathrm{mM}$ of $\mathrm{MgCl}_{2}$, and ultra-pure water quantum satis (QS).

Amplification was carried out in a thermal cycler (PTC200, Bio-Rad Laboratories Inc., Waltham, Massachusetts, United States) under the following conditions: the DNA template was initially denatured at $94^{\circ} \mathrm{C}$ for 5 min followed by 35 cycles of 1 min denaturation at $94^{\circ} \mathrm{C}, 1 \mathrm{~min}$ primer annealing at $60^{\circ} \mathrm{C}$, and $1 \mathrm{~min}$ extension at $72^{\circ} \mathrm{C}$. The reaction was completed with a $7 \mathrm{~min}$ final extension at $72^{\circ} \mathrm{C}$. For the semi-nested PCR, $1 \mu \mathrm{L}$ of the primary amplification template was added to $49 \mu \mathrm{L}$ of a reaction mixture containing the inner primers, and the program was repeated. Both EHV-1 DNA positive and negative (water) controls were run for all PCR assays. The PCR products were loaded onto $1 \%$ agar gel, and electrophoresis was carried out at $100 \mathrm{~V}$ for $70 \mathrm{~min}$ in Tris-acetate ethylenediamine tetraacetic acid (EDTA) buffer (Invitrogen, Carlsbad, California, United States) —a 1× trisacetate-EDTA (TAE) buffer solution contains 40 mMTrisacetate and $1 \mathrm{mM}$ EDTA at $\mathrm{pH}$ 8.3. The gel was stained with $0.5 \mu \mathrm{g} / \mathrm{mL}$ ethidium bromide, and DNA bands were visualized on a ultraviolet (UV) transilluminator. Negative amplifications were repeated at least once to detect the presence of PCR inhibitors. To determine the analytical sensitivity, EHV-1 strains with $10^{-3} / 25 \mu \mathrm{L} \mathrm{TCID}_{50}$ were serially 10 -fold diluted. The $460 \mathrm{bp}$ second-round product was detected at a dilution of $10^{-9}$, the highest dilution returning a positive semi-nested PCR result. 


\section{RESULTS}

Of the 105 animals, two fetuses (designated fetus 1 and 2) were positive for EHV-1 by PCR (Table 1). One positive animal came from the state of São Paulo, while the origin of the other one was not reported. The gestational ages of the positive aborted fetuses were not reported.

Fetus 1 [Laboratory of Anatomy Pathology (LAP) 56517] showed positive reactions with PCR and virus isolation in suspensions of liver, lung, CNS, kidney, and spleen, but negative by IHC. The lesions found in liver consisted of multifocal hepatitis with multiple small necrosis foci, discrete mononuclear inflammatory infiltrate and hepatocyte turbid degeneration. Lungs showed pleural and interstitial congestion, edema, and moderate mononuclear inflammatory infiltrate. The CNS exhibited meningeal congestion, lymphocytic marginalization, neuropil congestion, edema, mononuclear perivascular cuff, and gliosis. Heart showed discrete inflammatory mononuclear infiltrate in the epicardium, and white pulp hyperplasia was observed in spleen. Kidney was without noticeable lesions.

Fetus 2 (LAP 58048) was positive by PCR in liver, lung, kidney, and spleen and negative by viral isolation and IHC of the examined organ tissues. The lesions in liver comprised severe congestion of hepatic sinusoids with hepatocyte swelling, periportal fibrosis with moderate mononuclear infiltrate and proliferation of biliary ducts, discrete mononuclear capsular infiltrate, and intranuclear eosinophilic inclusion bodies and syncytia. In kidney, nephrosis, discrete interstitial mononuclear infiltrate, and intranuclear eosinophilic inclusion in the tubular epithelium were found. In lung, intense interstitial mononuclear inflammatory infiltrate with syncytia was observed (Fig. 1), and intranuclear eosinophilic inclusion bodies were present in the bronchiolar and alveolar epithelium (Fig. 2) with intense pleural edema and congestion with mononuclear infiltrate. The CNS exhibited intense congestion of the meninges and neuropil, elongated cortical neurons, intranuclear eosinophilic inclusion bodies in astrocytes, discrete meningeal mononuclear inflammatory infiltrate, perineuronal and perivascular edema, mononuclear perivascular cuff and gliosis.

Table 1.Diagnosis of equine herpesvirus 1 in two fetuses by virus isolation, polymerase chain reaction, immunohistochemistry, and histology (haematoxylin and eosin - H\&E).

\begin{tabular}{lcc} 
Technique & Fetus 1 & Fetus 2 \\
Virus isolation & (LAP 56517) & (LAP 58048) \\
\hline PCR & + & - \\
\hline IHC & + & + \\
\hline H\&E & - & - \\
\hline
\end{tabular}

+: Positive; -: negative; PCR: polymerase chain reaction; IHC: immunohistochemistry; H\&E (+): presence of syncytia and eosinophilic intranuclear inclusion bodies.

\section{DISCUSSION}

EHV-1 is recognized as one of the main causes of abortion in mares (HONG et al., 1993; MOREIRA et al., 1998; LAUGIER et al., 2011). In this study, the occurrence of EHV-1 was measured using PCR, H\&E staining, and IHC in organ tissues of aborted equine fetuses, stillbirths, and 1 month of age foals from regions of Brazil. The majority of the analyzed samples came from the state of São Paulo, followed by Paraná, Rio de Janeiro, and Minas Gerais, probably due to their proximity to the research laboratory.

Two fetuses were found positive for EHV-1, confirmed by PCR, representing $1.9 \%(2 / 105)$ of the sampled animals. Previous studies in Brazil and other countries have reported miscarriage rates due to EHV-1 infection ranging from 3.3 to $16.0 \%$ (HONG et al., 1993; MOREIRA et al., 1998; SZEREDI et al., 2003a; LÉON et al., 2008; SZEREDI et al., 2008; LAUGIER et al., 2011;

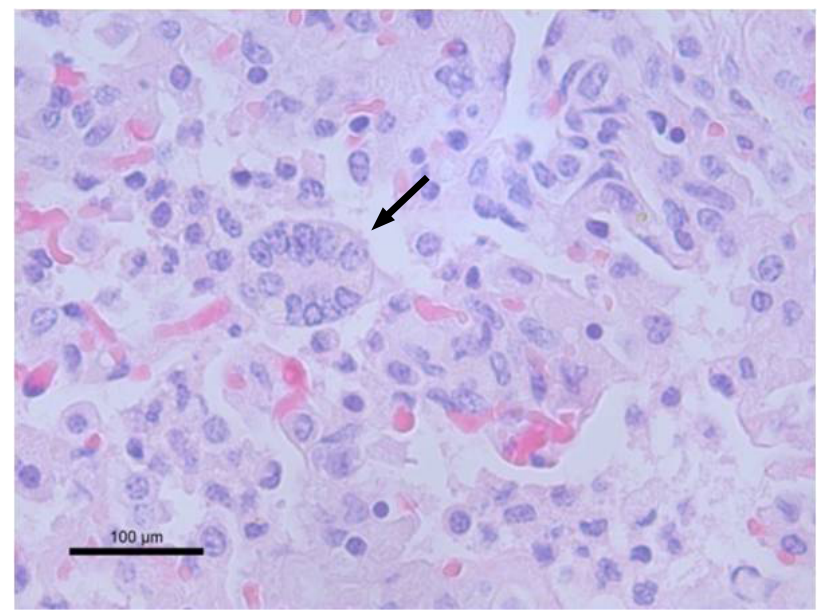

Figure 1. Aborted equine fetal lung tissue (Fetus 2). Syncytium

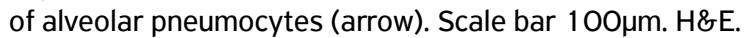

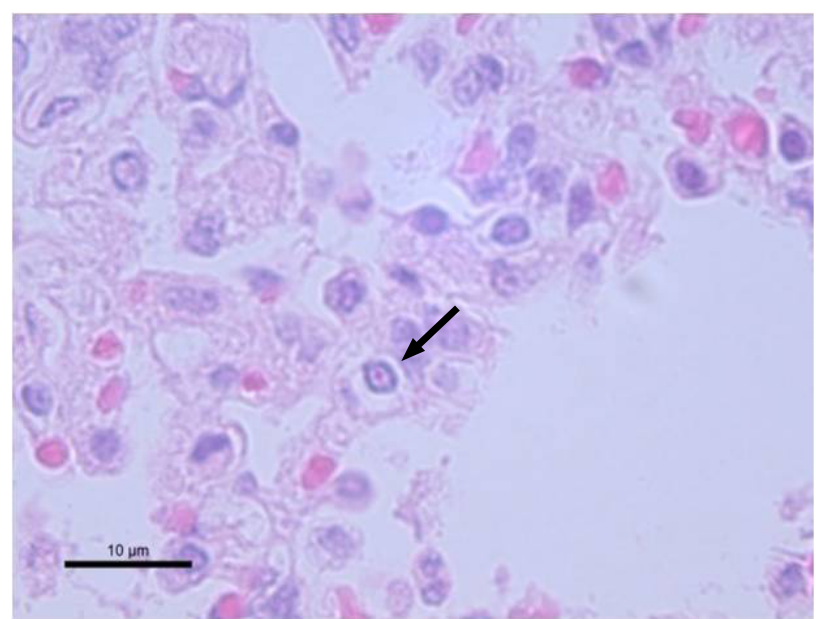

Figure 2. Aborted equine fetal lung tissue (Fetus 2). Intranuclear acidophilic inclusion body of alveolar pneumocytes at necrosis

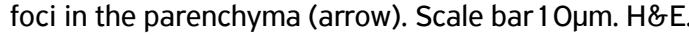


MARCOLONGO-PEREIRA et al., 2012). In contrast, seroepidemiological surveys in Brazil and other countries reported EHV-1 seropositivity rates of $17.7-52.48 \%$ in horses with no clinical signs (CUNHA et al., 2009; LARA et al., 2010; AGUIAR et al., 2008; ALENCAR-ARARIPE et al., 2014; YILDIRIM et al., 2015), and latent rates from 54.0 to $88.0 \%$, indicating high EHV-1 distribution and endemicity (CARVALHO et al., 2000; ALLEN et al., 2008; PUSTERLA et al., 2012).

Maternal humoral protection associated with increased routine vaccination, as well as improvements in environmental and nutritional management in animal husbandry, may have led to a decline in EHV-1 abortion rates, but the reactivation of latent virus must also be considered (ALLEN, 2002; SMITH, 1993; LUNN et al., 2009; BAŻANÓW et al., 2014; DAMIANI et al., 2014). In this study, although the dam of fetus 2 had been given routine vaccination, it was not protected from abortion. The vaccination status of the dam of fetus 1 was not reported.

These data are corroborated by HONG et al. (1993) and BROWN et al. (2007), who reported that vaccination against EHV resulted in a dramatic reduction in the number of cases, but that abortion continued in a small number of animals, a condition that the authors associated with viral latency and reactivation related to immunosuppressive states.

In the present study, the gestational age of the abortion or death was not available for 44 animals, including the two positive fetuses. Thus, it was not possible to establish a correlation between gestational age of the abortion and the disease, although it is well known that abortion induced by EHV-1 is largely restricted to the last trimester of pregnancy (LUNN et al., 2009). The absence of information such as geographic source of infected animal, vaccine status, age of death or gestational stage of abortion make epidemiological correlations difficult, so greater attention to providing complete information upon sample sent to research laboratories is necessary.

Histological evidence of herpesvirus infection was observed in several organs, and intranuclear eosinophilic inclusion bodies and syncytia are characteristic of EHV-1 in aborted tissue (ALLEN, 2002; OIE, 2015). However, as observed here and in other investigations, their occurrence can be transitory. Hence, the absence of these lesions does not necessarily indicate absence of herpesvirus infection, and the final diagnosis must be supported by laboratory testing (DEL PIERO, 1999; SZEREDI et al., 2003a). Equine adenovirus type 1 is a respiratory pathogen that can also cause intranuclear inclusion bodies in bronchial and bronchiolar epithelial cells in infected foals, and must be considered in the differential diagnosis in foal tissue (MCCHESNEY et al., 1970).

As seen in fetus 2 , negative viral isolation may not mean that the virus is absent in the sample or that it did not cause the disease, since the preservation of the sample may interfere with the viability of the virus (OIE, 2015), and the sensitivity of cell lines can vary significantly. Therefore, diagnosis based on this technique alone can lead to false negative results (BALASURIYA et al., 2015).

PCR has been recommended and widely used in routine diagnosis and research in EHV-1 for its rapid execution and yield of results, and for its sensitivity compared to other techniques (OIE, 2015; LUNN et al., 2009). The semi-nested PCR is described as a technique with high specificity, but with possibility of false positive results, while standard and real-time PCR present high specificity, although with possibility of false negative results (BALASURIYA et al., 2015).

To increase the accuracy, numerous studies of EHV-1 in aborted fetuses and foals have used combined methods, including virus isolation, in situ hybridization, IHC, indirect immunofluorescence, histology and PCR (SZEREDI et al., 2003a; HORNYÁK et al., 2006; SZEREDI et al., 2003b; WHITWELL et al., 1992). For latency studies, specific techniques have been recommended, such as the detection of the virus in buffy coat cells by co-cultivation and PCR (BALASURIYA et al., 2015).

In the present study, the small number of positive samples, even with the use of different techniques including the semi-nested PCR, confirms the low occurrence of EHV-1 in the studied population and suggests that the use of a single technique for EHV-1 may lead to false negative results (BALASURIYA et al., 2015; HORNYÁK et al., 2006). The combined approach may be useful to increase the likelihood of an accurate diagnosis of EHV-1.

\section{ACKNOWLEDGEMENTS}

We thank the Coordination for the Improvement of Higher Education Personnel (CAPES) for scholarship grants, and the São Paulo Research Foundation (FAPESP) for funding the investigation (Research Assistance number 2012/00277-0). 
AGUIAR, D.M.; CAVALCANTE, G.T.; LARA, M.C.C.S.H.; VILLALOBOS, E.M.C.; CUNHA, E.M.S.; OKUDA, L.H.; STÉFANO, E.; NASSAR, A.F.C.; SOUZA, G.O.; VASCONCELLOS, S.A.; LABRUNA, M.B.; CAMARGO, L.M.A.; GENNARI, S.M. Prevalência de anticorpos contra agentes virais e bacterianos em equídeos do município de Monte Negro, Rondônia. Amazônia Ocidental Brasileira. Brazilian Journal of Veterinary Research and Animal Science, v.45, n.4, p.269-276, 2008.

ALLEN, G.P. Epidemic disease caused by equine herpesvirus-1: recommendations for prevention and control. Equine Veterinary Education, v.14, n.3, p.136-142, 2002. DOI: $10.1111 /$ j.20423292.2002.tb00157.x

ALLEN, G.P.; BOLIN, D.C.; BRYANT, U.; CARTER, C.N.; GILES, R.C.; HARRISON, L.R.; HONG, C.B.; JACKSON, C.B.; POONACHA, K.; WHARTON, R.; WILLIAMS, N.M. Prevalence of latent, neuropathogenic equine herpesvirus- 1 in the Thoroughbred broodmare population of central Kentucky. Equine Veterinary Journal, v.40, n.2, p.105110, 2008. DOI: 10.2746/042516408X253127

ALENCAR-ARARIPE, M.G.; MAIA, D.C-B.S.C.; CAMPELO, C.C.; SILVA JÚNIOR, A.; SILVA, M.C.; DIAS, A.V.; MEDEIROS, C.M.O.; NUNES-PINHEIRO, D.C.S. Evidências sorológicas de EHV-1/ EHV-4 em cavalos de vaquejada no estado do Ceará, Brasil. Revista Brasileira de Higiene e Sanidade Animal, v.8, n.2, p. 203-217, 2014.

BALASURIYA, U.B.; CROSSLEY, B.M.; TIMONEY, P.J. A review of traditional and contemporary assays for direct and indirect detection of Equid herpesvirus 1 in clinical samples. Journal of Veterinary Diagnostic Investigation, v.27, n.6, p.673-687, 2015. DOI: $10.1177 / 1040638715605558$

BAŻANÓW, B.A.; FRĄCKA, A.B.; JACKULAK, N.A.; STARONIEWICZ, Z.M; PLOCH, S.M. A 34-year retrospective study of equine viral abortion in Poland. Polish Journal of Veterinary Sciences, v. 17 , n.4, p. 607-612, 2014.

BROWN, J.A.; MAPES, S.; BAШ, B.A.; HODDER, A.D.; LIU, I.K.; PUSTERLA, N.Prevalence of equine herpesvirus- 1 infection among Thoroughbreds residing on a farm on which the virus was endemic. Journal of the American Veterinary Medical Association, v.23 1, n.4, p.577-580, 2007.

CARVALHO, R.; OLIVEIRA, A.M.; SOUZA, A.M.; PASSOS, L.M.; MARTINS, A.S. Prevalence of equine herpesvirus type 1 latency detected by polymerase chain reaction. Archives of Virology, v.145, n.9, p.1773-1787, 2000. DOI: 10.1007/s007050070055

CHOMCZYNSKI, P. A reagent for the single-step simultaneous isolation of RNA, DNA and proteins from cells and tissue samples. BioTechniques, v.15, n.3, p. 532-4, 536-7, 1993.

CRABB, B.S.; STUDDERT, M.J. Equine herpesvirus 4 (equine rhinopneumonitis virus) and 1 (equine abortion virus). Advances in Virus Research, v.45, p.135-190, 1995. DOI: 10.1016/ S0065-3527(08)60060-3
CUNHA, E.M.S.; VILLALOBOS, E.M.C.; NASSAR, A.F.C.; LARA, M.C.C.S.H.; PERES, N.F.; PALAZZO, J.P.C.; SILVA, A.; STEFANO, E.; PINO, F.A. Prevalência de anticorpos contra agentes virais em equídeos no sul do estado de São Paulo. Arquivos do Instituto Biológico, v.76, n.2, p.165-171, 2009.

DAMIANI, A.M.; DE VRIES, M.; REIMERS, G.; WINKLER, S.; OSTERRIEDER, N. A severe equine herpesvirus type 1 (EHV1) abortion outbreak caused by a neuropathogenic strain at a breeding farm in northern Germany. Veterinary Microbiology, v. 172 , n.3-4, p.555-562, 2014. DOI: 10.1016/j.vetmic.2014.06.02

DEL PIERO, F. Comparison of equine arteritis virus and equine herpesvirus 1 findings in aborted fetuses. Journal of Equine Veterinary Science, v.19, p.562, 1999.

FERNANDES, W.R. Mieloencefalopatia protozoótica dos equinos. Arquivos do Instituto Biológico, v.61, n.2, p.7-10. 1999.

HONG, C.B.; DONAHUE, J.M.; GILES, R.C.; PETRITES-MURPHY, M.B.; POONACHA, K.B.; ROBERTS, A.W.; SMITH, B.J.; TRAMONTIN, R.R.; TUTTLE, P.A.; SWERCZEK, T.W. Equine abortion and stillbirth in central Kentucky during 1988 and 1989 foaling seasons. Journal of Veterinary Diagnostic Investigation, v.5, n.4, p.560566, 1993.

HORNYÁK, Á.; BAKONYI, T.; KULIK, M.; KECSKEMÉTI, S.; RUSVAI, $M$. Application of polymerase chain reaction and virus isolation techniques for detection of viruses in aborted and newborn foals. Acta Veterinaria Hungarica, v.54, n.2, p.271-279, 2006.

LARA, M.C.C.S.H.; CUNHA, E.M.S.; VILLALOBOS, E.M.C.; NASSAR, A.F.C.; ASANO, K.M.; FERNANDES, W.R.; RICHTZENHAIN, L.J; BRANDÃO, P.E.; MORI, E. First isolation of equine herpesvirus type 1 from a horse with neurological disease in Brazil. Arquivos do Instituto Biológico, v.75, n.2, p.221-224, 2008.

LARA, M.C.C.S.H.; TORELLI, C.S.; CUNHA, E.M.S.; VILLALOBOS, E.M.C.; CUNHA, M.S.; BELLO, A.C.P.P.; CUNHA, A.P.; REIS, J.K.P.; LEITE, R.C.; MORI, E. Inquérito sorológico da infecção por herpesvírus equino no Estado de Minas Gerais. Brazilian Journal of Veterinary Research Animal Science, v.47, n.5, p.352-356, 2010.

LAUGIER, C.M.; FOUCHER, N.; SEVIN, C.; LEON, A.; TAPPREST, J. A 24-Year Retrospective Study of Equine Abortion in Normandy (France). Journal of Equine Veterinary Science, v.31, n.3, p. 116 123, 2011 . DOI: 10.1016/j.jevs.2010.12.012

LÉON, A.; FORTIER, G.; FORTIER, C.; FREYMUTH, F.; TAPPREST, J.; LECLERCQ, R.; PRONOST, S. Detection of equine herpesviruses in aborted fetuses by consensus PCR. Veterinary Microbiology, v. 126 , n.1-3, p.20-29, 2008. DOI: 10.1016/j.vetmic.2007.06.019

LUNN, D.P.; DAVIS-POYNTER, N.; FLAMINIO, M.J.B.F.; HOROHOV, D.W.; OSTERRIEDER, K.; PUSTERLA, N.; TOWNSEND H.G.G. Equine Herpesvirus- 1 Consensus Statement. Journal of Veterinary Internal Medicine, v.23, n.3, p.450-461, 2009. DOI: 10.1111/j.1939-1676.2009.0304.x 
MARCOLONGO-PEREIRA, C.; ADRIEN, M.L.; LADEIRA, S.R.L.; SOARES, M.P.; ASSIS-BRASIL, N.D.; SCHILD, A.L. Abortos em equinos na região Sul do Rio Grande do Sul: estudo de 72 casos. Pesquisa Veterinária Brasileira, v.32, n.1, p.22-26, 2012. DOI: 10.1590/SO100-736X2012000100005

MCCHESNEY, A.E.; ENGLAND, J.J.; ADCOCK, J.L.; STACKHOUSE, L.L.; CHOW, T.L. Adenoviral infection in suckling Arabian Foals. Pathology Veterinary, v.7, n.6, p.547-564, 1970.

MOREIRA, N.; KRÜGER, E.R.; WARTH, J.F.G.; BIESDORF, S.M.; GOULARTE, M.M.M.; WEISS, R.R. Aspectos etiológicos e epidemiológicos do aborto equino. Archives of Veterinary Science, v.3, n. 1, p.25-30, 1998. DOI: 10.5380/avs.v3i1.3735

MORI, E.; MORI, C.M.C.; MASSIRONI, S.M.G.; CUNHA, E.M.S.; VILLALOBOS, E.M. C.; LARA, M.C.C.S.H.; FERNANDES, W.R. Detection of equid herpesvirus 1 DNA by Polymerase Chain Reaction after experimental inoculation of horses with a Brazilian A4/72 strain. Brazilian Journal of Veterinary Research Animal Science, v.46, n.4, p.253-261, 2009.

OIE. WORLD ORGANIZATION FOR ANIMAL HEALTH. Manual of Diagnostic Tests and Vaccines for Terrestrial Animals. Chapter 2.5.9. Equine rhinopneumonitis. 2015. Available from: <http://www.oie.int/fileadmin/Home/eng/Health_standards/ tahm/2.05.09_EQUINE_RHINO.pdf >. Accessed on: May 292015.

PROPHET, E.B.; MILLS, B.; ARRINGTON, J.B.; SOBÓN, L.H. Métodos Histotecnológicos. Washington, D.C.: Registro de Patología de los Estados Unidos de América y Instituto de Patología de las Fuerzas Armadas de los Estados Unidos de América, 1995. 280p.

PUSTERLA, N.; MAPES, S.; DAVID WILSON, W. Prevalence of latent alpha-herpesviruses in Thoroughbred racing horses. Veterinary Journal, v. 193, n.2, p.579-82, 2012. DOI: 10.1016/j. tvjl.2012.01.030

RUIZ-SÁENZ, J.; GÓEZ, Y.; LÓPEZ-HERRERA, A. Detección de ADN de herpesvirus equino tipos 1 y 4 en mononucleares de sangre periférica y ganglio trigémino de equinos: infección, latencia y una aproximación a laneuropatogénesis de la cepa circulante. Revista Colombiana Ciência Pecuárias, v.2 1, p.372-386, 2008.

SMITH, B.P. Tratado de medicina veterinária interna de grandes animais: moléstias de equinos, bovinos, ovinos e caprinos. 1. ed. v.1. São Paulo: Manole, 1993. 537p.

SZEREDI, L.; PÁLFI, V.; MOLNÁR, T. Comparison of methods for the diagnosis of equine herpesvirus type 1 infection. Acta Veterinaria Hungarica, v.51, n.2, p.153-163, 2003a. DOI: 10.1556/AVet.51.2003.2.3

SZEREDI, L.; AUPPERLE, H.; STEIGER, K. Detection of equine herpesvirus- 1 in the fetal membranes of aborted equine fetuses by immunohistochemical and in-situ hybridization techniques. Journal of Comparative Pathology, v.129, n.2-3, p.147-153, 2003b.

SZEREDI, L.; TENK, M.; JÁNOSI, S.; PÁLFI, V.; HOTZEL, H.; SACHSE, K.; POSPISCHIL, A.; BOZSÓ, M.; GLÁVITS, R.; MOLNÁR, T. A survey of equine abortion and perinatal foal losses in Hungary during a three-year period (1998-2000). Acta Veterinaria Hungarica, v.56, n.3, p.353-367, 2008. DOI: 10.1556/AVet.56.2008.3.9 0236-6290/\$

WELCH, H.M.; BRIDGES, C.G.; LYON, A.M.; GRIFFITHS, L.; EDINGTON, $\mathrm{N}$. Latent equid herpesviruses 1 and 4 : detection and distinction using the polymerase chain reaction and co-cultivation from lymphoid tissues. Journal of General Virology, v.73, p.261-268, 1992. DOI: $10.1099 / 0022-1317-73-2-261$

WHITWELL, K.E.; GOWER, S.M.; SMITH, K.C. An immunoperoxidase method applied to the diagnosis of equine herpesvirus abortion, using conventional and rapid microwave techniques. Equine Veterinary Journal, v.24, n.1, p.10-12, 1992. DOI: $10.1111 /$ j.2042-3306.1992.tb02770.x

YILDIRIM, Y.; YILMAZ, V.; KIRMIZIGUL, A.H. Equine herpes virus type 1 (EHV-1) and 4 (EHV-4) infections in horses and donkeys in northeastern Turkey. Iranian Journal of Veterinary Research, v.16, n.4, p.341-344, 2015. 